\title{
Just and Unjust Killing
}

\section{NOLEN GERTZ}

Department of Philosophy, New School for Social Research, USA

Abstract To provide a way to understand warfare and debate military conduct, Michael Walzer's Just and Unjust Wars tries to show that civilians and soldiers are not separated by a barrier of violence as we might think, but rather inhabit the same moral world. While this view enables us to question and criticize our leaders during times of war instead of simply claiming ignorance, its success is gained by obscuring certain fundamental boundaries that exist between combatants and noncombatants. By comparing Walzer's just war theory with the existential theories of Jean-Paul Sartre and Martin Heidegger, we can therefore find a more complete picture of what it means to declare war and what it means to engage in combat. This will allow us to see that what separates the soldier from the civilian is our everyday avoidance of death and anything associated with it. Through an investigation into the relationship between death and killing we can then ask, from an existential standpoint, whether we can call any war "just" so long as our evasion of death also results in our evasion of what soldiers must go through to protect us, thus preventing the soldier from being able to truly return home.

Key Words: Just war theory, existentialism, rights, aggression, coercion, death, killing

\section{Introduction-Walzer's Hell}

Though Michael Walzer's classic text, Just and Unjust Wars, is most likely best known for bringing just war theory into the modern era, it is perhaps his dissection of the adage "War is hell" that is deserving of more attention. For Walzer this familiar saying is not merely a platitude to be taken for granted or tossed into a discussion whenever we feel that there is simply nothing more to say on the subject. Rather it is exactly this sort of habit that Walzer challenges throughout the work, as he argues that its appearance as a piece of warrior wisdom masks the true logic behind its use. To define war in this manner is to place it 


\section{Just and Unjust Killing}

outside the boundaries of the mundane world and, more importantly, outside the realm of morality, thus freeing those who fight wars from the judgments of those who do not.

However, as Walzer tries to show, war is a human activity open to criticism and condemnation like any other, requiring that we do not mistake the whole (jus ad bellum) for the sum of its parts (jus in bello).

And yet, though Walzer argues against the "“war is hell' doctrine" (Walzer 2006: 3233) in order to bring war into the moral arena, his evidence for this view hinges on what he believes history can teach us about "the experience of war as hell" (Walzer 2006: 31). Although the difference between stating that war "is hell" and the perception of war "as hell" might seem to be only grammatical, for Walzer this distinction is of the utmost importance; the argument surrounding the former stresses the need to set limits to the use of force in war while the argument surrounding the latter stresses the need to avoid war at all costs. It is the seeming contradiction between these two stances - to condemn that which we can occasionally justify, so long as it is done in the right way for the right reasons - that Walzer seeks to clarify throughout the book, as it appears that the attempt to debate the possibility of a "just war" will always result in a paradoxical position so long as, simultaneously, "we regard life and liberty as something like absolute values" (Walzer 2006: xxiv).

What is of particular importance for us here though is the theory of human rights that Walzer relies on to underpin the moral imperatives behind these two positions, along with his central claim that aggression is the mark of criminality (Walzer 2006: 21), which provides the basis for the "justified struggle" against belligerence that creates the tension between these two positions. By focusing on these issues we will come to see that such rights as "life and liberty" do not apply to all equally, as any political community requires that some members risk their rights in the defense of the rights of the others. This risk, however, does not merely come from the danger of battle, but from the very act of going to battle, for, as Walzer points 
out, to kill another (or to even threaten to kill another), is to renounce one's membership in the community and to lose the rights grounded in that membership. If this assessment is correct, then we must ask how it is that a society gains the right to ask its citizens to defend the rest and become exiles in the process. Furthermore, is it then possible to later regain one's lost citizenship, as Walzer suggests, and to be welcomed back into the community? This paper will therefore investigate these questions and attempt to determine what it means for a society to declare war and whether a soldier can ever truly come home again.

\section{Declaring War}

From a very early age, children know that they can possibly avoid being punished for fighting by being the first to yell out "He started it!" It is then up to the adult at the scene to piece together what took place so as to determine if the child was justified in his actions or if he deserves some of the blame for the fight as well. For Walzer, this situation is an example of a "domestic analogy" (Walzer 2006: 58), which can help us to better see that the true dynamics of war are not as complex as they may at first appear. Thus, like a child on a playground, so too do the leaders of a nation at war publicly proclaim that their actions are justified by blaming the other side for creating the situation that has ultimately brought about the hostilities. The parallel between these two scenarios holds, according to Walzer, because "it makes sense to say that territorial integrity and political sovereignty can be defended in exactly the same way as individual life and liberty" (Walzer 2006: 54). We therefore individually have the right not to be bullied just as communally we have the right not to be invaded, and in both cases we have the right to fight back.

But does this mean that Walzer thinks that parents, and the international community, should accept the "He started it!" defense as valid? His answer: "Aggression is the name we give to the crime of war. [...] The wrong the aggressor commits is to force men and women 


\section{Just and Unjust Killing}

to risk their lives for the sake of their rights" (Walzer 2006: 51). To be attacked is to be challenged in such a way that demands self-defense; however, we should not take this demand to simply mean that we must defend ourselves in the physical sense of protecting against harm, as it can be argued that, for Walzer, the challenge issued by aggression is also an attack on the self, or community, in an existential sense (what we mean by this will be explained shortly). Though Walzer certainly does not engage in existential argumentationand at times even appears hostile to it ${ }^{1}$ - he does make several claims that suggest that if "aggression is morally as well as physically coercive" (Walzer 2006: 53), then this is because aggression must also be existentially coercive.

That existentialism must play a part in Walzer's theory of human rights can already be seen in his arguments for when the use of force is called for by either an individual or society in self-defense. Whether discussing the rights of "life and liberty" or "territorial integrity and political sovereignty," to contend that these are "rights that are worth dying for" (Walzer 2006: 53), that "the triumph of aggression is a greater evil [than war]" (Walzer 2006: 68), that "our common values are confirmed and enhanced by the struggle" (Walzer 2006: 71), and that "there are threats with which no nation can be expected to live" (Walzer 2006: 85), shows that there is more being protected in fighting back than simply the physical or moral aspects of our lives. If we are to meet hostility with hostility, and are willing to take lives from those who would take ours, then the motivation for taking such physical risks through such morally questionable behavior must come from some meaning that we attach to our lives that is not fully explained by either of these two domains.

As this argument for a missing existential "meaning" in Walzer's theory could be seen as merely a negative proof of its existence, we should look more closely at his discussion of individual and social rights to find evidence for a positive proof as well. Walzer connects the personal level of rights with the political level through the idea of there 
being a "common life" that individuals create in and through the forming of communities, and which becomes the bearer of the collective rights of all involved. As Walzer writes,

Over a long period of time, shared experiences and cooperative activity of many different kinds shape a common life. "Contract" is a metaphor for a process of association and mutuality, the ongoing character of which the state claims to protect against external encroachment. The protection extends not only to the lives and liberties of individuals but also to their shared life and liberty, the independent community they have made, for which individuals are sometimes sacrificed. The moral life of any particular state depends upon the reality of the common life it protects and the extent to which the sacrifices required by that protection are willingly accepted and thought worthwhile. (Walzer 2006: 54)

We can see in this argument that what is important for the creation of a community is not biological, geographical, religious, or historical determinations, but rather the "shared experiences and cooperative activity" of the individuals involved. This then suggests that what brings these people together, and what is deemed so important that one may be "sacrificed" for it, is something akin to what Jean-Paul Sartre defines as a "fundamental project."

According to Sartre, what separates humans from objects is that we are determined only to the extent that we allow ourselves to be, as we are nothing other than what we create through our actions. Hence the meaning we attach to things, to people, to places, derives from our relationship to them insofar as they are involved in our freely chosen activities, or "projects," through which we identify ourselves. In Being and Nothingness therefore, Sartre argues that "human reality—as we have attempted to establish—identifies and defines itself by the ends which it pursues," or what he otherwise refers to as "its free project, which is the impulse by which it thrusts itself toward its end" (Sartre 1956: 712). However, Sartre makes clear that his theory is not solipsistic, as the project that I choose and that I am does not take place in a vacuum but rather in the midst of the world, among other beings and other projects. 


\section{Just and Unjust Killing}

I can therefore recognize another through her project just as she can recognize me through mine, and yet there is still a more "fundamental project" that we all share, i.e. the “original project of living” (Sartre 1956: 721). As Sartre writes,

\footnotetext{
This fundamental desire in turn expresses concretely in the world within the particular situation enveloping the individual, an abstract meaningful structure which is the desire of being in general; it must be considered as human reality in the person, and it brings about his community with others, thus making it possible to state that there is a truth concerning man and not only concerning individuals who can not be compared. Absolute concreteness, completion, existence as a totality belong then to the free and fundamental desire which is the unique person. (Sartre 1956: 724-725)
}

We can now try to connect this account with Walzer's by suggesting that this "free and fundamental desire" to create ourselves through our projects is not only what leads us into "community with others," but is also what ultimately grounds the rights that Walzer asserts are "worth dying for." Life and liberty, like integrity and sovereignty, are clearly "absolute values" only to the extent that, as a human being, I am capable of giving value to my life through the very liberty that defines my being. If this were not the case, if I were not so constituted as to define myself through my actions, then aggression could not be coercive in the way that Walzer requires, for then there could be no hope of a "just war," and every "He started it!" defense would only mask acts of revenge.

\section{Sending the Troops}

Our investigation into Walzer's theory has so far covered the justification for the use of force in self-defense, but it does not yet apply to the use of force in war. To return to our previous example, we can explain this distinction by suggesting that though the child who is being attacked has the right to fight back, at this point there is no justification for his sending someone else to do the fighting for him. Hence, to follow this domestic analogy back to the 
other side, we must say that if we as a society are to declare war, then so far we only have the right to do so if every citizen were to take up arms. And yet, though we would punish a child for sending another to fight in his place, it is of course common practice for a citizenry to enter into war by staying at home while their soldiers head off to battle in their name. Surprisingly, Walzer does not try to extend his arguments about rights to validate this societal use of troops, but instead criticizes this practice based on his view of war as hell.

As we have already seen, though Walzer argues that our "common life" requires "sacrifice" to protect it if it is endangered, he qualifies this claim by adding that such risks must be "willingly accepted and thought worthwhile." Walzer's measuring stick for determining the moral nature of the possible reasons for soldiers entering battle is therefore "the extent to which war (as a profession) or combat (at this or that moment in time) is a personal choice that the soldier makes on his own and for essentially private reasons" (Walzer 2006: 28). Accordingly, at one end of the spectrum he places wars, predominantly ancient and feudal, fought by those who chose to participate - such as aristocrats who thought of war as a sport, soldiers who relished battle, and paid mercenaries — as "they seek out the excitement of battle, perhaps because they enjoy it, and their subsequent fate, even if it is very painful, can't be called unjust" (Walzer 2006: 26). On the other side we find the cases where the soldiers had no such freedom—-such as mercenary armies composed of soldiers who joined out of necessity or national armies composed of soldiers who fight out of patriotic duty — as in both situations Walzer claims that it is a "crime" to use such troops since "war is hell whenever men are forced to fight, whenever the limit of consent is breached" (Walzer 2006: 28).

While we would certainly agree with Walzer that we should not condone the exploitation of an individual's needs in order to raise an army, it is difficult to place those who enlist "as a matter of conscience" into the same category of "political instruments" as 


\section{Just and Unjust Killing}

those who "go to war under constraint" (Walzer 2006: 28-29). Walzer's coupling together of these two groups seems to require that we liken the need to feed oneself or one's family to the need to defend one's country, which would entail that neither situation would allow an individual to exercise their freedom in choosing not to fight. He writes,

\footnotetext{
...the more a soldier fights because he is committed to a 'common cause,' the more likely we are to regard it as a crime to force him to fight. We assume that his commitment is to the safety of his country, that he fights only when it is threatened, and that then he has to fight (he has been 'put to it'): it is his duty and not a free choice. He is like a doctor who risks his life during an epidemic, using professional skills he chose to acquire but whose acquisition is not a sign that he hopes for epidemics. (Walzer 2006: 27)
}

The comparison between the dutiful soldier and the brave doctor however suggests that the basis for Walzer's condemnation is not solely due to the exploitation of the necessities of survival for the purposes of recruitment, but is instead more focused on the supposition that for either a soldier or a doctor it is circumstances beyond their control that forces them into action. It is in this sense that Walzer describes the duty-bound as "victims" and compares them to "nonparticipating civilians," insofar as he takes it for granted that "the soldiers would almost certainly be nonparticipants if they could" (Walzer 2006: 30).

The form of citizenship that would follow from Walzer's argument appears to be quite at odds with the more traditional view that we can enjoy the benefits of what a state can offer only to the extent that we accept and fulfill the duties (e.g. paying taxes, obeying laws) the state requires in return. While we might admit that it is unfortunate to be sent to war, would we truly want to say that it is also a "crime"? Do we not include as part of the argument for the rights to "life and liberty" the responsibility for what comes from how one chooses to use these rights in creating the "common life" of one's nation? In opposition to this view, Walzer delimits the responsibility of the soldier in wartime by arguing that modern 
democracy, rather than increasing our responsibilities, only "increases the legitimacy of the state and then the effectiveness of its coercive power" (Walzer 2006: 35; emphasis added). Thus, in a rather strange twist, Walzer's definition of aggression as coercion, which previously required that we defend our "common life" and allowed us to do so justly, has now become coercion as aggression, such that when my nation is endangered, or at the very least engaged in a war, I should fight only because I decided it was worth it, for otherwise I had to have been forced into what he calls "military servitude." As Walzer concludes, "Hence the moral reality of war can be summed up in this way: when soldiers fight freely, choosing one another as enemies and designing their own battles, their war is not a crime; when they fight without freedom, their war is not their crime" (Walzer 2006: 37).

This view of soldiers as either "unwilling participants" or as "pawns" coerced through "their routine habits of law-abidingness, their fear, their patriotism, their moral investment in the state" (Walzer 2006: 39) reveals a tension between Walzer's position and Sartre's. Whereas previously we had tried to connect Walzer's physico-moral arguments about the relationship between the individual and the community to Sartre's existentialism, it now appears that there is a deeper division between these two sides that had gone unnoticed. Walzer claims that we must "recognize the existence of authority structures and socialization processes in the political community" (Walzer 2006: 40n) so that we can separate the political leader's responsibility for the fact of war (jus ad bellum) from the soldier's responsibility in the reality of combat (jus in bello). In stark contrast to this, Sartre would find the concept of an "unwilling participant" to be an oxymoron, insofar as he argues that we cannot possibly be forced into taking any action since we are always already forced to be free.

As we have already seen, for Sartre I am what I make of myself in and through my actions. The caveat to this view that human existence is defined by freedom is that "absolute 
responsibility...is simply the logical requirement of the consequences of our freedom." He continues,

If I am mobilized in a war, this war is $m y$ war; it is in my image and I deserve it. I deserve it first because I could always get out of it by suicide or by desertion; these ultimate possibles are those which must always be present for us when there is a question of envisaging a situation. For lack of getting out of it, I have chosen it. This can be due to inertia, to cowardice in the face of public opinion, or because I prefer certain other values to the value of the refusal to join in the war (the good opinion of my relatives, the honor of my family, etc.). Any way you look at it, it is a matter of a choice. [...] Of course others have declared it, and one might be tempted perhaps to consider me as a simple accomplice. But this notion of complicity has only a juridical sense, and it does not hold here. [...] There was no compulsion here, for the compulsion could not have got hold on a freedom. (Sartre 1956: 708-709)

According to this argument, a soldier must always accept responsibility for fighting in a war to the extent that alternative options were not chosen instead. While we might be tempted to disagree with Sartre that we can simply assert that suicide is a "choice," the point still remains the same, that I "deserve" my "situation" as it could not have taken place without my having been the author of it. A soldier can only define his war as honorable or criminal, his service as proud or shameful, because his actions and his environment have no meaning other than what he gives them.

Thus if it can be argued that I can be "coerced" into defending my freedom insofar as it is the very meaning of my being to be free-it is in this sense that we can understand Sartre's point that "I am responsible for everything, in fact, except for my very responsibility...therefore everything takes place as if I were compelled to be responsible" (Sartre 1956: 710) — then we cannot at the same time argue that war is "the king's business a matter of state policy, not of individual volition, except when the individual is the king" (Walzer 2006: 39). We can see in the distinction between these two positions that it is only 
by returning to the soldier the responsibility that Walzer has removed that we can make the subsequent move to return to society the right to send soldiers into war. According to Walzer's stance there will always be a conflict between the rights of the individual and the rights of the community, as the community will always have the power of the "king" over any individual, and therefore the best case scenario in wartime would be one that is similar enough to World War II to allow soldiers to view their war as just and their enlistment as voluntary. However, in Sartre's schema the individual is always "king," which therefore removes any tension between the individual and the community, since the right of the community to enter into war is grounded upon the same freedom that gives the soldier the right to refuse to serve.

\section{Trying to Come Home}

If we can now say that a child being bullied has the right to "recruit" a friend to defend him, as the friend always has the right to say no, then we must next inquire as to what happens when the friend says yes. In such a situation we can expect that the child most likely feared his aggressor and that is why he went to his friend in the first place. So how is the child to react when his friend too becomes an aggressor? Will their relationship remain the same as before, or will the child be incapable of dissociating the violence of his enemy that he feared from the violence of his friend that he hid behind? To attempt to answer these questions we must first determine what it means to call someone my enemy and someone else my friend, and how it is that one can possibly become the other.

While we do not find in Walzer something akin to Schmitt's friend/enemy distinction, we can locate something closer to a tripartite division of innocent/victim/aggressor. The innocent is any noncombatant, and what separates them from the other two classes is their "immunity" from all harm. According to Walzer, we need not investigate "how immunity is 


\section{Just and Unjust Killing}

gained, but how it is lost," as, in his view, "we are all immune to start with; our right not to be attacked is a feature of normal human relationships" (Walzer 2006: 145n). Thus we are all born into innocence, and we are able to remain in this state so long as we do not break this fundamental human bond by attacking another. As Walzer points out—with reference to the writings of several soldiers - there are even instances in war where an enemy combatant can appear as though innocent once more by simply partaking in "normal" activities, such as bathing, smoking, or having a morning coffee. In such situations, the soldier does not, and perhaps cannot, take advantage of the "nakedness" of his adversary, as he finds his opponent to be "entirely dissociated from anything threatening" (Walzer 2006: 141), and therefore once again as someone not to be harmed.

Although we may disagree with Walzer that humans can be thought of as having been born with the "right not to be attacked"-such a view would seem to conflict with an existential conception of humanity insofar as it implies that humans have an essence (immunity) that would precede our existence (life and liberty) since it could not be derived from our existence — our focus lies instead with how this claim of innocence leads to the corresponding charge of guilt. For if we draw the line between these two classifications at the attempt to injure another, or even at appearing as "threatening" to another, then how do we distinguish the violence of our soldiers from the violence of theirs? Furthermore, if Walzer argues that a soldier "alienates himself from me when he tries to kill me, and from our common humanity" (Walzer 2006: 142), then how can such actions, on either side, ever be considered to be "just"? Walzer's answer:

The case [of the "naked soldier"] might be different if we imagine this man to be a wholehearted soldier. In his bath, smoking his morning cigarette, he is thinking only of the coming battle and of how many of his enemies he will kill. He is engaged in war-making just as I am engaged in writing this book; he thinks about it all the time or at the oddest moments. But this is an unlikely picture of an ordinary soldier. War is not in fact his enterprise, but 
rather surviving this battle, avoiding the next. Mostly, he hides, is frightened, doesn't fire, prays for a minor wound, a voyage home, a long rest. And when we see him at rest, we assume that he is thinking of home and peace, as we would be. (Walzer 2006: 142-143)

What separates a soldier-as-victim from a soldier-as-aggressor therefore is the idea that though they may carry out the same actions, only one acts in a "wholehearted" manner. It would appear then that what truly sets a soldier apart is not whether he tries to kill me- - $\mathrm{He}$ has been made into a dangerous man, and though his options may have been few, it is nevertheless accurate to say that he has allowed himself to be made into a dangerous man" (Walzer 2006: 145)—but whether he actually wants to kill me.

Although this argument may make sense in the context of combat, where one "dangerous man" can judge the intentions of another by referring to his own experiences and feelings, Walzer does not provide us with any reason to think that "innocent" individuals outside of this context could do the same. In fact, he instead appears to argue against such a possibility. Walzer does begin from the standpoint that there is no "realm of force" separate from our own (WALZER 2006: 7), as we can all assess the actions of soldiers by "asking what we would have done (or what we would do) in similar circumstances" (Walzer 2006: 9). However, he later claims that "soldiers as a class are set apart from the world of peaceful activity; they are trained to fight, provided with weapons, required to fight on command," which "radically distinguishes the individual soldier from the civilians he leaves behind" (Walzer 2006: 144). The tension we find between these two positions indicates that there is something closer to Schmitt's friend/enemy distinction in Walzer's account after all, for it would appear that the separation on the battlefield between the "ordinary" and "wholehearted" soldier inevitably collapses into the single category of "dangerous men" once any soldier attempts to return to the "world of peaceful activity."

Here we can see that our analogy on the playground no longer applies to the particular 


\section{Just and Unjust Killing}

problems on the battlefield, or even on the homefront. The child is able to directly witness what his friend does in order to defend him, whereas civilians are forced to rely on such indirect sources as stories from past wars, representations in the media, and their own imaginations for any information about what happens when soldiers are sent out in their defense. Although this may allow the public to view their military as a whole with pride and offer them their support, the situation tends to change when confronted with an individual soldier returning from combat, as perhaps best exemplified by the almost uncontrollable urge most people have to ask the soldier, "Did you kill anybody?" Though such questions may appear harmless, they do indicate that there is a wide, unbridgeable gulf between the combatant and the noncombatant, that will ensure that the latter will continue to see the former as a "dangerous man," regardless of any "prosaic acts" (Walzer 2006: 142) he may try to re-identify himself through.

Hence, if the soldier loses the capacity to define himself before others through his acts, then this must be the result of something that has changed for the soldier from an existential standpoint. As we have already seen, Walzer's physico-moral view allows for the soldier to return to society unchanged, as the "alienating" nature of his "threatening" appearance only lasts so long as the appearance does, thus the soldier's "humanity" is "restored" (Walzer 2006: 142) with the laying down of his arms. However, while this claim may make sense in theory, it leaves out of consideration certain elements of the practical world that reveal why the returning soldier is seen as "veteran" more than "neighbor." To better understand why there is such a separation between going off to battle and staying at home that can continue to "alienate" the soldier long after the war has ended, we must investigate the place that death occupies in everyday life. For no matter what else we may say about it, the common view of war ultimately centers on death and sees the soldier as little else than its practitioner. ${ }^{2}$ 
While Sartre has helped us to explore the meaning of our lives, it is Martin Heidegger that can be of more help to us here in achieving an understanding of the meaning of death. ${ }^{3}$ According to Heidegger, when someone is dying we have a tendency to try to comfort them by telling them that everything will be ok, that they'll "make it." Rather than seeing this as simply an attempt to console someone in need, Heidegger interprets this as a way to provide an anesthetic against death for both the listener and the speaker. Along with this, we also tend to avoid speaking of death directly, and when we do, it is often in an abstract manner that turns it from something that will happen to each of us and could potentially happen at any time into something that happens to other people or in the distant future. As Heidegger argues, we even go so far as to try "tacitly regulating the way in which one has to comport oneself towards death," as it is generally considered as "cowardly" and a "sign of insecurity" to be "thinking about death" (Heidegger 1962: 254). Thus, in our "idle talk," death is dissolved of its existential meaning for us as a phenomenon that we can take up as what is most ours and ours alone and direct ourselves toward, and instead we only mention death "in a 'fugitive' manner, either expressly or else in a way which is mostly inhibited, as if to say, 'One of these days one will die too, in the end; but right now it has nothing to do with us"' (Heidegger 1962: 253).

With this formulation, we can now say that if our mundane way of dealing with death is to treat it as a "mishap" (Heidegger 1962: 253), as something that happens to others but that I could perhaps somehow avoid, then the return of a soldier from the battlefield either forces us to try to free ourselves of such attitudes and inclinations and to "face death," or it forces us to try to free ourselves of the soldier. In other words, the soldier-clothed not just in military uniform, but in training, discipline, language, stories, habits, behaviors—stands out from the rest of us, almost as an alien intruder, for we know that the soldier has "seen things" and "done things" that we cannot imagine and perhaps, more importantly, do not 
want to imagine. This situation can thus be understood as a necessary consequence of what Heidegger refers to as our "everydayness," as our involvement in, and identification with, the "they". He writes,

In this inconspicuousness and unascertainability, the real dictatorship of the "they" is

unfolded. We take pleasure and enjoy ourselves as they take pleasure; we read, see, and judge about literature and art as they see and judge; likewise we shrink back from the 'great mass' as they shrink back; we find 'shocking' what they find shocking. [...] Thus the "they" maintains itself factically in the averageness of that which belongs to it, of that which it regards as valid and that which it does not, and of that to which it grants success and that to which it denies it. In this averageness with which it prescribes what can and may be ventured, it keeps watch over everything exceptional that thrusts itself to the fore. (Heidegger 1962: 126-127)

An individual who chooses to leave the comfort of the community to go off to war is at the same time therefore choosing to leave the comfort of the "they", and in the process becomes someone "exceptional." It does not matter whether the soldier actually killed, was almost killed, or saw someone else be killed, for the very fact that any or all of these experiences are seen as possible in war is enough to separate the soldier irrevocably from the "they" of the mundane world of work, family, recreation, etc., for whom these experiences are distinctly not seen as possible in their daily lives. Hence the soldier is welcomed back into this world with trepidation, for fear that these possibilities that surround the soldier will somehow return from that world as well.

\section{Conclusion-The Meaning of Killing}

Walzer has presented us with a picture of war that allows for communities to be forced into fighting, individuals to be forced into becoming soldiers, and combatants to become noncombatants again by terminating any show of force. Sartre and Heidegger have helped us to try to fill-in this picture by indicating what the existential conditions of 
possibility would be for such coercion, enlistment, and homecoming to take place. However, as this has so far given us a predominantly community-based view of warfare, we have not yet investigated the meaning of combat for the soldier. Though we have seen that the community sees war as something negative, as "mere butchery," can we, as members of the community, understand alternatively how a soldier sees war, as well as his or her role in it? Walzer attempts to find an answer to this question through an analysis of how soldiers in past wars have responded to those situations_-such as the "My Lai Massacre" during the Vietnam War - that would most reveal the soldier's willingness or unwillingness to kill and, consequently, the soldier's acceptance or refusal of the aforementioned "war is hell' doctrine."

By looking at memoirs, novels, and official reports detailing the activities of soldiers regarding the treatment of prisoners and civilians during combat, Walzer finds evidence that soldiers are not in fact "mere instruments" (Walzer 2006: 306) who are "caught in the grip of war" (Walzer 2006: 310). His interpretation of the actions of those soldiers that did not simply kill blindly when the situation presented itself is that it indicates that all soldiers are still capable of making "appeals at such a time to common moral standards" (Walzer 2006: 316). As Walzer writes,

The teaching process [for soldiers] has the form of an endless drill, aimed at breaking down their individual thoughtfulness, resistance, hostility, and waywardness. But there is some ultimate humanity that cannot be broken down, the disappearance of which we will not accept. [...] Trained to obey "without hesitation," they remain nevertheless capable of hesitating. I have already cited examples of refusal, delay, doubt, and anguish at My Lai. These are internal confirmations of our external judgments. No doubt we can make these judgments too quickly, without hesitations and doubts of our own, paying too little attention to the harshness of battle and the discipline of the army. But it is a mistake to treat soldiers as if they were automatons who make no judgment at all. Instead, we must look closely at the particular features of their situation and try to understand what it means, in these circumstances, at this 
moment, to accept or defy a military command. (Walzer 2006: 311-312)

Walzer is here suggesting that soldiers are still sufficiently connected to the moral world that they can judge whether or not to obey an order to kill, or in other words, when it is "right" or "wrong" to kill. Yet, if this is the case, if the "teaching process" of soldiers is able to bring them to a point where they can be capable of killing while still maintaining "some ultimate humanity," then what does such an attempt at combining the morality of the "world of peaceful activity" with the "harshness of battle" do to the soldier? What is important here therefore is not to determine "what it means" for a soldier to "accept or defy a military command," but rather our concern must be to determine what it means for an individual to have already become so accustomed to the possibility of killing to be able to even take a meaningful stance towards such commands.

As we have already seen, in our everydayness death is transformed into something that we could possibly escape, and is thus thought of as only happening to those who were unfortunate, as though it were merely an illness. However, if we continue with this Heideggerian picture of the relation between death and the "they", then how might we describe the relation between killing and the "they"? Though Heidegger is able to encapsulate the view of the "they" towards death in the expression "one dies" (Heidegger 1962: 253), it is certainly impossible to find a parallel expression such as "one kills" or "one is killed" in mundane life. Killing is so little thought of as a real possibility in the "world of peaceful activity" that it is more often used in reference to the effect of a joke or being tickled than with regards to the potentiality of any of us killing, or being killed by, another. This could be due to the fact that killing is not an existential phenomenon in the same way that death is, for it is not something that we can take up as most ours and ours alone, but rather killing is only something that we can choose to makes ours or that we can be forced to make ours. Whereas to be born is to be dying, it is only through attempting to kill that I can 
become a killer, just as it is only through having my life put in danger that I can become a victim of killing.

To be able to obey or refuse an order to kill therefore requires that the soldier has already taken up killing as a real possibility. While we tend to try to describe the effects of this through such terms as "refusal, delay, doubt, and anguish," this only serves to mask the distance between the "they" and the battlefield. To say that a soldier refused to kill, or felt anguish at being asked to kill, is to suggest that we can possibly understand what it is that the soldier is experiencing by drawing comparisons to our own feelings and actions (e.g. refusing the request of a friend, anguish over a difficult decision) in our everyday lives. This perhaps explains why the diagnoses given to soldiers who display particular symptoms in warfare often contain references to symptoms found in more ordinary situations, as for example found in combat fatigue, shell shock, and post-traumatic stress disorder. Here then we find a process similar to what was discovered with regards to death, that is, the generalizing of an existential phenomenon such that it can be ignored or only talked about in an indirect and abstract manner. This way of dealing with killing then produces an even larger separation between the soldier and the community; just as the community views the soldier as someone who has "seen things" or "done things," so too does the soldier come to see the community as those who "don't know what it was like." Thus so long as we employ a military and continue to fight wars without at the same time attempting to actually understand what death and killing mean, the soldier will always be kept at a distance, used to protect us from enemies while being exiled to protect us from reality. Although we have the right to declare war, we therefore do not yet have the right to declare it "just."

\section{Notes}

${ }^{1}$ Cf. Walzer 2006: 204-6.

${ }^{2}$ For evidence that Walzer too sees this as the common view of war, and perhaps shares it, cf. Walzer 2006: 45 


\section{Just and Unjust Killing}

(emphasis added): "Though chivalry is dead and fighting unfree, professional soldiers remain sensitive (or some of them do) to those limits and restraints that distinguish their life's work from mere butchery. No doubt, they know with General Sherman that war is butchery, but they are likely to believe that it is also, simultaneously, something else."

${ }^{3}$ Sartre sees Heidegger's claim that we "flee" before death as only important to the extent that it shows that "we wish to hold on to life" (Sartre 1956: 721), yet, as it is only through Heidegger's analysis of death that we can understand how life relates to death, it would appear that Sartre's lack of a comparable analysis is an attempt at "flight" as well.

\section{References}

Heidegger, M. (1962) Being and Time, trans. John Macquarrie and Edward Robinson. (Oxford: Blackwell Publishing Ltd.).

Sartre, J.-P. (1956) Being and Nothingness, trans. Hazel E. Barnes. (New York: Washington Square Press).

Walzer, M. (2006) Just and Unjust Wars, fourth Edition. (New York: Basic Books). 